\title{
European Business Ethics agenda based on a Delphi analysis
}

\author{
Leire San-Jose ${ }^{1,2^{*}}$ (i) and Jose Luis Retolaza ${ }^{3}$
}

\begin{abstract}
Purpose: This paper examines the flow of thoughts on Business Ethics research lines from experts of European countries.

Design/methodology/approach: A Delphi method was used to achieve consensuses among the perceptions and opinions of experts about Business Ethics matters. Moreover, the research agenda is investigated using a Delphi process developed with the participation of 12 experts from eight countries (France, Spain, the UK, the Netherlands, Sweden, Switzerland, Germany, and Hungary) from March to September 2015.

Findings: The state of the art based on the expert panel's consensuses on the emerging issues in Business Ethics permits the early detection of emerging lines, thus narrowing the research line and decreasing subject selection time. Additionally, an active research map has been constructed based on researchers, countries, and lines of investigation.

Originality/value: There is a gap in the representation of the research on certain management topics in Business Ethics, so this research will constitute a significant and valuable tool for novel researchers. It is useful for creating a research agenda.
\end{abstract}

Keywords: Consensus, Panel, Europe, Social responsibility, Research

\section{Introduction}

There are many topics in each research line. Business Ethics is not different in this regard [40], and there are many different issues integrated as Business Ethics topics and problems. The aim of this paper is to establish the most important issues in Business Ethics. We will ask Business Ethics experts a range of questions to determine their views about the emergent issues in Business Ethics to develop a research agenda.

The purpose of this paper is to illustrate, based on actual Business Ethics academic experts' perspectives, the future of suggested topics that will probably be relevant for scholars working in topics of Business Ethics or related fields in Europe. In general, the European approach to Business Ethics places more emphasis on economics and on social structures and less emphasis on the activities of corporations than the US approach does [7]. A priori, the list will be extended probably without limit, perhaps because of the idiosyncrasies of the authors. However,

\footnotetext{
* Correspondence: leire.sanjose@ehu.eus

${ }^{1}$ University of the Basque Country, UPV/EHU, Bilbao, Spain

university of Huddersfield, Huddersfield, UK

Full list of author information is available at the end of the article
}

we will show that some of the most important experts in this field in Europe could agree about expected future research lines in this regard.

We have decided to apply the Delphi method because it has some advantages compared with other methods, such as surveys, interviews, or focus groups. The experts that participate are extremely honest, they do not feel group pressure, and feedback is helpful for them. The method is based on the consensus, but argumentation and discussion are key elements during the process, and the costs are reduced when the experts are physically in different countries. Therefore, we have used a Delphi method with the participation of 12 experts from eight European countries (France, Spain, the UK, the Netherlands, Sweden, Switzerland, Germany, and Hungary) from March to September 2015.

This study will contribute to providing a healthy picture of the discipline, in line with the research of Werhane and Freeman [40] years ago. Moreover, the prediction of topics will be helpful for new and novel researchers in the area in terms of increasing their confidence about the interest in the topics in which they are going to contribute or in 
terms of detecting the topics and the researchers that have previously researched those topics. It will be easier with the mature theories in the Business Ethics field. It will be helpful for doctoral studies because it will reduce the confusing first months of their dissertation process if this dynamic is generalized and recognized by the academy.

The structure of the remainder of this paper is as follows. We first describe the literature about the Delphi method and analyze the situation of the papers published in the area using the Journal Citation Report of Thomson Reuters (followed using Social Science Citation Index-SSCI) and the country as the criterion because it is the purpose of this research to establish only the European vision of the Business Ethics research agenda. Next, we present our data gathering and analysis procedures, the Delphi process and information about the selection of experts, and steps for applying a successful and rigorous methodology. The results show the more valued topics by experts, a brief explanation of each topic's current situation, the active map of researchers detected in each area, and the opinions of experts about the progress in Business Ethics topics (panel). At the end, the concluding remarks and references are presented.

\section{Overview of Business Ethics concept and literature: a European view}

Although Business Ethics is a relatively young area of study, the relationship between ethics and economics is an old one [13]. According to the 1998 Nobel Prize in Economic Sciences winner Amartya Sen, there is an important link among economics and ethical theory. Thus, Business Ethics is a form of applied ethics that concerns the business world [20]. Although we have used the term Business Ethics throughout this paper, it is difficult to agree on a unique term for a similar concept and use only that term worldwide. More importantly, there are sometimes different understandings of the same term. Such is the case with "ethics in the company or business," which is described by different terms at different levels of application. Among the terms used, we can find words in different languages such as the following: "business ethics," "Wirtschaftsethik," "Unternehmensethik," "Éthique économique," "éthique des affaires," "economic ethics," and "ética de empresa." Sometimes, these terms are used as synonyms, but sometimes the difference is crucial. However, it is possible (at least from a moral perspective) to agree that Business Ethics should take into account three different levels: micro (or individual), meso (or the organizational level), and macro (or the system view). In this line, Enderle [9] proposes answering three questions to analyze moral problems in economic areas: what is done, what can be done, and what should be done. It has been proposed to use these three perspectives (person, organization, and system) with the aim to establish a complete analysis in which personal dilemmas, corporate social responsibility, and the ethical implications of the socio-economic system are analyzed and interconnected to obtain a complete moral perspective of Business Ethics. However, the misunderstanding comes from both the term used and the country-effect for understanding. In this regard, Enderle [9] states that in Europe, the preferred issues are those related to the macro level, and only by using indirect analysis are the ethical gaps included. Then, ethics and corporate or Business Ethics actions are facing gaps, particularly considering legality. In other places, such as North America, the micro (person) approach is the key. Therefore, from this view, the direct approach is easier, and the options to address Business Ethics problems are from the bottom up. Coming back to Europe, the view of this paper permits us to say that Europeans emphasize macro issues. In their rationale, they take into account some of the issues that are found at the micro level, especially from psychological rather than philosophical perspectives. Only recently have European research and experts clearly included the meso issues [9]. Recently, meso analysis has become very important in Europe. Hence, the interest of this work in this line and the concern for the "ethics of organizations" and "corporate ethics" are very important.

In relation to the definition, there are a wide range of aspects that make the definition of Business Ethics very difficult, if not impossible (see [19]). For example, in one attempt to define Business Ethics, more than 150 textbooks were reviewed by Lewis [19] in the 1980s. He established that some bits are important, including the focus on social responsibility. the emphasis on honesty and fairness, the values that are in accord with the common ones, behavior in line with one's religious beliefs, the philosophy of what is good and bad, and the emphasis on virtue, leadership, and character. However, after the effort to group and link all subjects around Business Ethics, he concluded that "Business Ethics is more than just virtue, integrity, or character. It involves the application of one's understanding of what is morally right and truthful at a time of ethical dilemma" ([19], p. 383).

In this regard, the purpose of this research is not to establish the definition of Business Ethics, but rather the understanding of Business Ethics will be the root for defining the topics of the area. Then, it is clear that the moral and behavioral aspects surrounding Business Ethics are among the most important topics but are not the only ones. Thus, the aim of this paper is to establish the consensus of emergent Business Ethics topics from a European perspective, the wide range of topics in the world and the potential different views about the meaning of Business Ethics (see, for example, the comparison between the US and European Business Ethics views in Palazzo, [26], Enderle [9] and Mele [22] or the Asian, 
American, and European views on ethical leadership in Resick et al. [29]. These are the reasons for establishing a narrow view in this step of the research.

In an attempt to understand the current situation of Business Ethics, we have decided to review the Business Ethics papers using a systematic and relevant process based on the selection of only those papers published in journals included in the Social Science Citation Index (SSCI) (for more information, see http://wos-ssci.fecyt.es/). Then, we have chosen the Web of Science because of its importance in academic publications. The collaboration of our Delphi participants and the certainty that the documents that have been found have been well documented give us the confidence to use this method. To search for all necessary issues, we have followed these steps: The first is the topic that we have entered into the Web of Science's search bar, "BUSINESS ETHIC*". The next step is to mark the categories that interest us, which are "BUSINESS" and "ETHICS." Finally, since this research is focused on Europe, we have chosen European countries and regions (the UK [England-Wales-Scotland-Northern Ireland], Spain, the Netherlands, France, Germany, Belgium, Sweden, Switzerland, Norway, Finland, Denmark, Italy, Portugal, Ireland, Slovenia, Cyprus, Austria, Hungary, Greece, Estonia, Poland, and the Czech Republic). Following all these steps, a total of 355 results on 28 May 2015 were shown in the Journal Citation Reports browser. These results helped us select the panel of experts who helped us with the Delphi methodology. Each country has a different number of articles. This information is illustrated in the following figure (see Fig. 1).

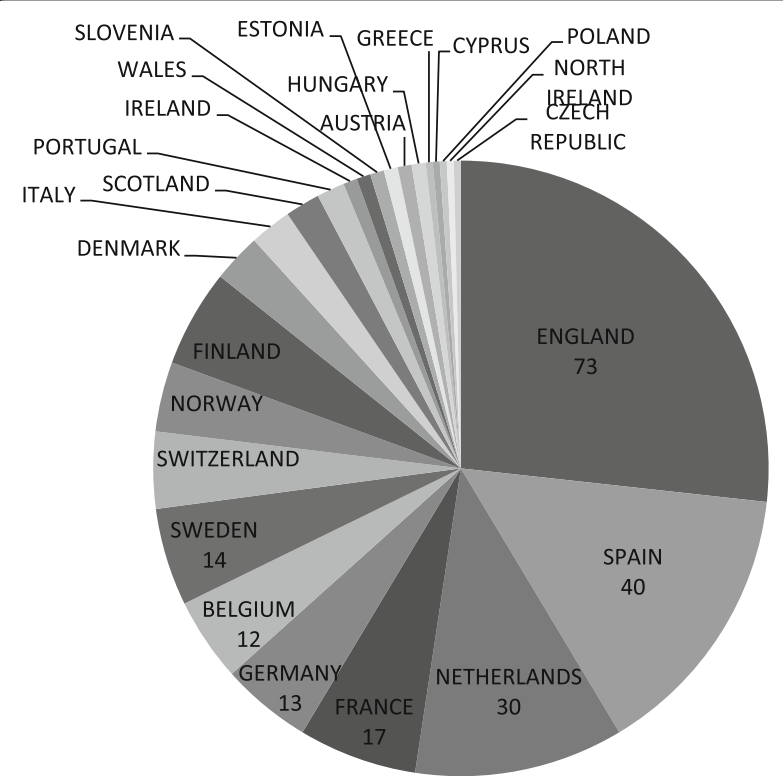

Fig. 1 Results of Business Ethics papers by European countries. Source: Own production
The region with the highest number of articles on Business Ethics is the UK (26.74\%), followed by Spain at $14.75 \%$ and the Netherlands at $10.99 \%$ of the total results. This means that these first three entities account for $52.48 \%$ of the total European Business Ethics publications. It is important to know that, over the years, there have been distinct differences in the numbers of published Business Ethics articles and their citations, which is illustrated in Fig. 2.

The graphic shows a significant increase from 2008 to $2015 .^{1}$ This increase could be because of the economic crisis. Once economic scandals started, Business Ethics became a topic of general interest. Academic experts on Business Ethics have noted that financial and general business scandals have harmed the reputation of many companies [10]. When this trust crisis started, people turned their attention to Business Ethics.

\section{Methodology \\ What is the Delphi method for?}

After a review of potential methodological tools (interview, survey, focus group, and Delphi), the Delphi method, although it is less used for Business Ethics research purposes, was selected because it is useful for determining the consensus from experts in different locations and eliminating the coercion effect [31].

The Delphi method is more linked to providing feedback and obtaining the largest consensus with a moderate assessment of the group and a high communication flow but with anonymity among participants $[2,24,25,27,38]$, which is the most important reason for selecting it over others to achieve the purpose of this research. Moreover, the Delphi method is suitable when the contributions of experts are highly dispersed, as in this case where the experts are from European different countries (e.g., [33]). Moreover, the Delphi method has moderate costs [25]. Therefore, it will be valid for this research question in which the consensus and the opinions of dispersed participants are important but there is not a budget for the research. In this regard, we have decided that an online survey was the most efficient tool for communicating with academic experts. The Delphi is not a modern method, as it has been developed since the 1960s [3, 36, 37]. However, now in the twenty-first century, its application has spread to the social area and especially to helping solve business research questions $[2,18,33]$.

To summarize, we have used the Delphi method because the consensus is necessary to achieve the goals of our research project. The Delphi method was developed at the RAND Corporation ${ }^{2}$ in the 1950s. This method is based on the results of several rounds of questionnaires that are sent to a panel of experts who are anonymous in relation to one another. When those rounds of questionnaires are sent out and the anonymous experts reply, the answers are 

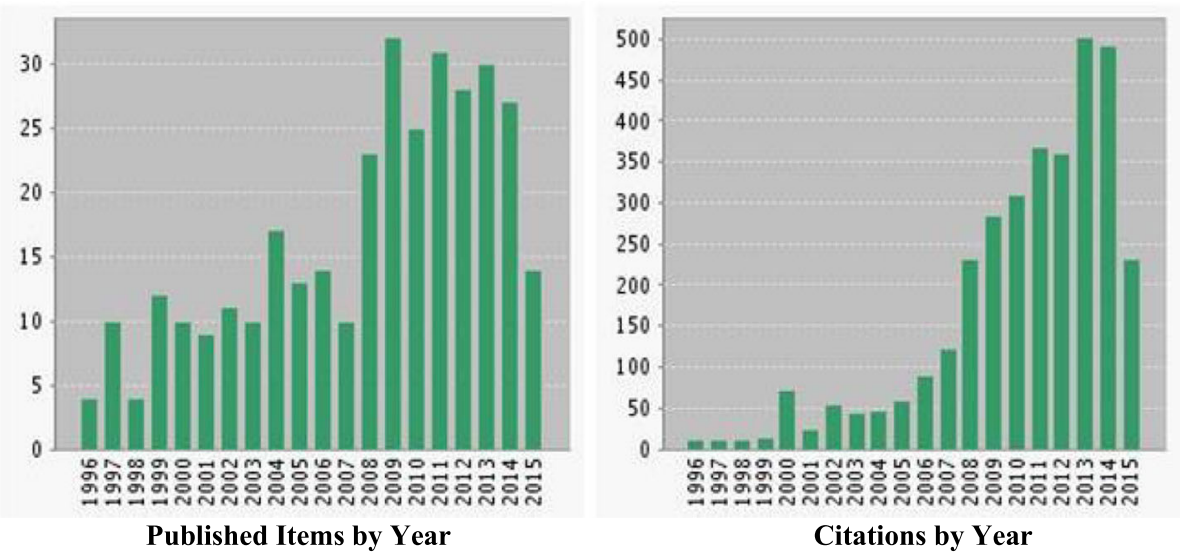

Fig. 2 Difference between published papers and citations. Source: Web of Science

collected and forwarded to the group after each round. There are multiple rounds of questions asked to a large number of experts. This review process and the direct relationship with the interviewer (Delphi organizer) establish a clear and transparent process for the experts. Additionally, this process eliminates the direct influence of the other experts. Furthermore, the experts are from different European countries, and this method permits the consideration of all of their opinions. Therefore, from our point of view and for our research purpose, the Delphi method is appropriate.
The main objective of the Delphi method was originally to obtain the most reliable consensus of opinions from a panel of experts by administering a series of questionnaires and obtaining controlled opinion feedback [18]. Such a consensus is clearly needed to establish the emergent issues of a topic based on the panel experts' opinions.

\section{The research process: step by step}

We have sent three rounds of questionnaires to experts in order to guarantee the efficiency of the methodology [5]. As we noted above, the aim of this Delphi method is

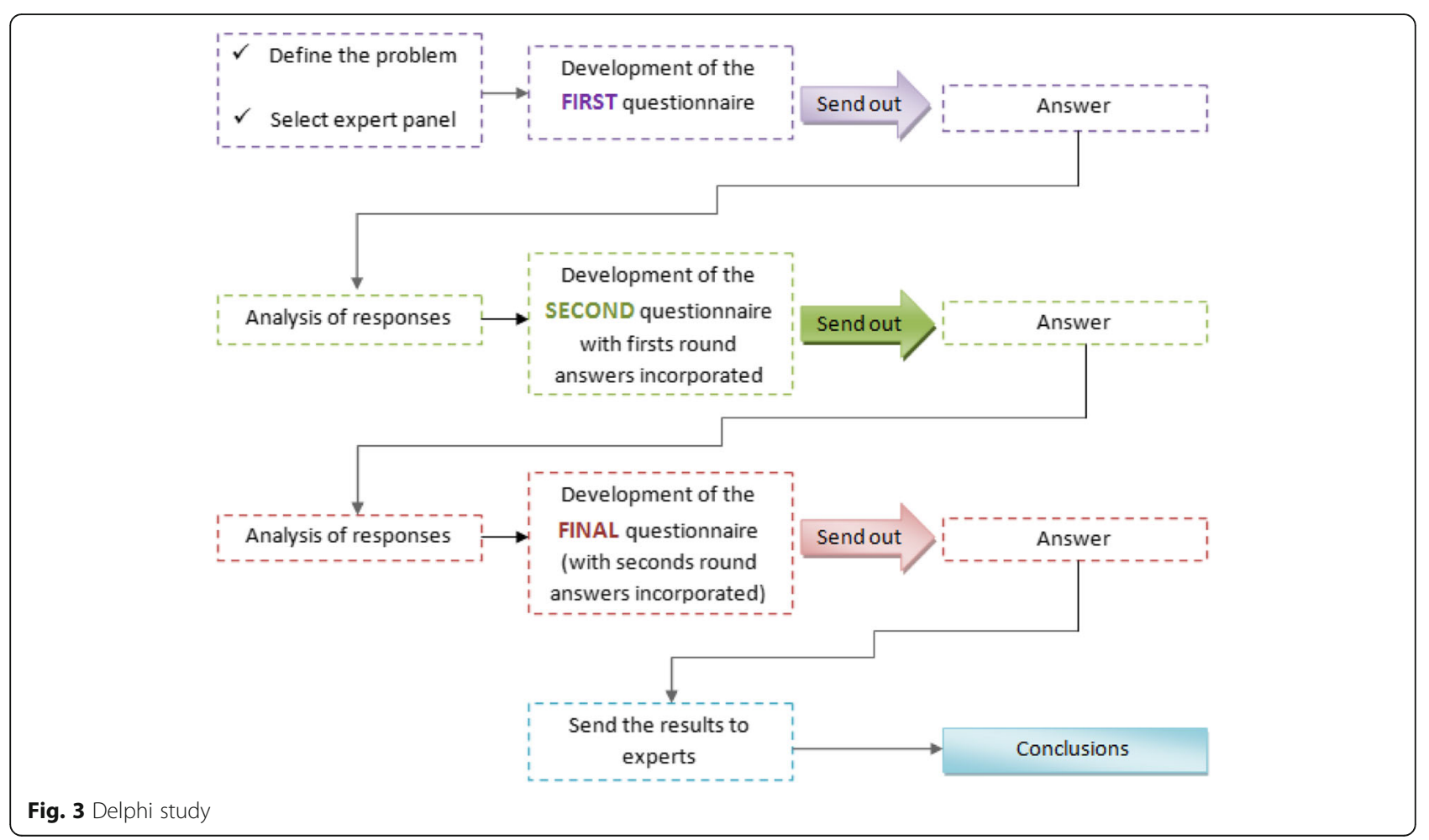


to consensually determine the Business Ethics areas of interest and emergent issues in Europe and the expected future of Business Ethics schools and research groups or centers in Europe. In this case, this method is an appropriate approach because it makes it possible to reach a consensus among experts and analyze the importance and the future of ethics in business. For the correct development of the approach, the selection of experts was exhaustively conducted as necessary to obtain significant results [25]. In this case, at least three papers included in Journal Citation Report journals about Business Ethics issues were required to be eligible as an academic Business Ethics expert. Additionally, some other Business Ethics experts were added because of the desire to take into consideration a wide representation of European countries that are relevant in terms of Business Ethics areas. We have the support of the ISBEE (International Society of Business, Economics and Ethics). The Business Ethics expert selection was checked by the ISBEE. The Delphi method has been considered adequate for the purpose of this research (to understand and know the issues that Business Ethics experts are interested in) and the criterion for selecting experts. Finally, the list of experts was approved by the ISBEE. All those decisions have been made through online contact (e-mail) and in a non-structured meeting of $47 \mathrm{~min}$ with the responsible party during 2015. The experts considered themselves as eligible for doing this analysis as they confirmed their level of knowledge about Business Ethics.

Then, in brief, the steps to apply a coherent Delphi method are as follows (see Fig. 3). First, we define the problem that we want to analyze. Depending on the aim, we need to select a panel of experts that will help us develop all the steps. Once we have the list of the experts who want to resolve the problem by working together on the research question, we administer a questionnaire (see Table 2).

\section{Briefing the data of the Delphi}

The experts are always anonymous to each other, but they are never anonymous to the researcher. That is why we did not send them personal information. We worked with a group of 12 experts in Business Ethics following the Delphi method (see Table 1), which is a $70.58 \%$ response rate for those selected. Eight European countries are represented (France, Spain, the UK, the Netherlands, Sweden, Switzerland, Germany, and Hungary). The Delphi method was conducted from March to September 2015. The most important European points of view are represented because of the disparity of the experts' countries. Moreover, the construct validity is guaranteed since the experts have (in all the rounds) the option to explain their opinion, comment on the results, or make suggestions without group pressure. They have accepted the groups and words

Table 1 Delphi data collected and analyzed

\begin{tabular}{|c|c|}
\hline Data collection & 10 March 2015 till 6 September 2015 \\
\hline Summary of procedure & $\begin{array}{l}\text { We have sent a questionnaire to European experts with } 3 \text { open questions. } \\
\text { Next, we designed another survey based on the responses to the first one. } \\
\text { Then, we finished with the third round, which was based on a rank questionnaire. }\end{array}$ \\
\hline Representativeness of Sample & $\begin{array}{l}\text { The Delphi panel experts were chosen using two criteria: } \\
\text { - Minimum of } 3 \text { Business Ethics papers published in high quality journals } \\
\text { (Journal Citation Report JCR). } \\
\text {. European experts. }\end{array}$ \\
\hline Sample size for statistical power and significant findings & $\begin{array}{l}\text { We selected } 17 \text { experts but } 12 \text { agreed to being our Delphi experts participants, } \\
\text { so the Delphi panel is made up of } 12 \text { experts. } \\
\text { Countries: Europe (France, Spain, UK, Netherlands, Sweden, Switzerland, } \\
\text { Germany, and Hungary). }\end{array}$ \\
\hline Construct validity & $\begin{array}{l}\text { It is guaranteed. Experts validate the interpretation and categorization of } \\
\text { the variables. Apart of questions there is also an open place to explain } \\
\text { their responds opinions or made some suggestions. }\end{array}$ \\
\hline Anonymity & All experts are anonymous in relation to one another, but never to the researcher. \\
\hline Non-response issues & 5 out of 29 iterations failed. \\
\hline Dropout rate & $\begin{array}{l}\text { There is only a dropout; one expert did not take part in the third round. } \\
\text { However, we provide the conclusions keeping this in mind. }\end{array}$ \\
\hline Round number & 3 rounds. Each round had three petitions for each expert. \\
\hline Time to respond & $\begin{array}{l}\text { An average of } 7.14 \text { days ( } 6.5 \text { days the first round; } 5.33 \text { days the second } \\
\text { round and } 9.6 \text { days the third round). }\end{array}$ \\
\hline Contact form & Email survey \\
\hline Survey type & Structured survey \\
\hline
\end{tabular}


used, and they have made their valuations in each round. Only five interactions failed during all the processes, and only one expert did not take part in the third round. This finding shows the high involvement and responsibility of the participants in the process. Apart from the high response rates, the process time (an average of 7.14 days) was quite fast, considering the responsibilities that these academic experts have at their universities.

The Delphi method was conducted via e-mail during 2015. We sent each expert the questions. Once we collected all of the responses, we analyzed and reviewed them and identified the similarities and differences in the first round. Then, we sent questions in the second round along with the collective answers of the experts, and so on. We used nine questions in total that were divided into three rounds. These questions are repeated throughout the different rounds (see Table 2).

In brief, the process was as follows. Once the first round of questions were answered, the response questions were collected and the questions adapted. Therefore, the questionnaires were modified during subsequent rounds by using the opinions and feedback from the participants. With a list of 22 emergent issues, more specific answers were necessary. It was time to send out the second round of questions. In this round, experts focused on inquiries that were more concrete. This questionnaire was composed of closed-ended questions. The last round was focused on having the most precise and correct answers. We aimed to define the situation of Business Ethics in Europe and establish the future research lines of interest for the scientific community. All the processes were based on the same objective, and some progress was made in each of the rounds. The final round consisted of more open questions that were based on the experts' previous answers. At the end of this questionnaire, the experts could include their opinions or reflections about the Delphi methodology and about Business Ethics in general.

We spoke with some of the Delphi panel experts after the Delphi process was finished, and they described their positive feelings, the objectivity in which the analysis was conducted, and their interest in the researchers' interpretation.

\section{Results}

After finishing the Delphi rounds with the participation of the 12 experts, we combined all responses. The results obtained are divided into three levels. First are the selected and detected emergent issues, followed by a short and easy explanation of the meaning of the most important emergent issues selected. In addition, a map of the experts who are doing some research in these subjects or at centers and institutes interested in those lines is shown. Of course, it is a map with a continued progression, but it is represented as a picture at the moment at which the Delphi was conducted. Finally, the opinion of the experts around the progression of the schools in each of their areas is represented and analyzed based on an exploratory view and based on their personal opinions.

\section{Development of Business Ethics emergent issues}

The experts noted 17 emergent issues in Business Ethics in Europe. Then, their opinions were sought regarding their thoughts and expectations of the development of each emergent issue in Business Ethics in Europe. In the next section, there is a short description of these emergent issues. The experts had the option to check and review those issues in the second round since the Delphi method is a consensus process in which the results of the previous

Table 2 Delphi's rounds: questionnaire and general results

\begin{tabular}{|c|c|c|}
\hline & Questionnaire & General results \\
\hline First round & $\begin{array}{l}\text { Formed by three general questions: } \\
\text { 1. Business Ethics keywords in Europe. } \\
\text { 2. Business Ethics research questions in Europe. } \\
\text { 3. The future emerging research lines in Business Ethics } \\
\text { in Europe. }\end{array}$ & $\begin{array}{l}\text { In this round, we grouped } 22 \text { emergent issues in Business } \\
\text { Ethics in Europe. }\end{array}$ \\
\hline Second round & $\begin{array}{l}\text { The second round questions are: } \\
\text { 1. Rank the importance of a list of emergent issues. } \\
\text { 2. Add any keyword. } \\
\text { 3. Mark } 5 \text { emerging issues that you think will have } \\
\text { the greatest relevance over the next } 10 \text { years. }\end{array}$ & $\begin{array}{l}\text { Once experts marked the more important emergent issues, } \\
\text { we kept } 17 \text { of them. } \\
\text { Furthermore, the six most relevant emergent issues in } \\
\text { Business Ethics are (depending on academic experts' opinions): } \\
\text { 1. Ethical competencies } \\
\text { 2. Behavioral ethics } \\
\text { 3. Digitalized culture, privacy, and ethics } \\
\text { 4. Spirituality } \\
\text { 5. Finance ethics } \\
\text { 6. Risk management }\end{array}$ \\
\hline Third round & $\begin{array}{l}\text { Third round questions: } \\
\text { 1. What do you think and how would you like to } \\
\text { develop each of these emergent issues? } \\
\text { 2. Business Ethics experts, institutions, or center in Europe. } \\
\text { 3. Business Ethics teaching in Europe. }\end{array}$ & $\begin{array}{l}\text { Finally, with the third round, we reached the results collected } \\
\text { below. (See the "Results" section) }\end{array}$ \\
\hline
\end{tabular}


step are shown to participants as general points. This does not betray the anonymity of the experts but does expose their ideas globally. Moreover, some of the experts after the Delphi process had the option to discuss their ideas in a public panel in 2015, and this was the evidence of the results' acceptance.

The following graphic (see Fig. 4) illustrates the difference between the level that the experts think that these emergent issues will develop during the next 10 years and the range of development they want to see. In the majority of cases, the level that experts think that these issues will develop is much lower than expected. Only in inequality, the crisis of water, CSR in social networks, diversity and integration, and digitalized culture, privacy and ethics is the development higher than they would like it to be. One of the emergent issues, local communities as stakeholders, does not differ between the range of "real" and desired development.

Ethical competencies and finance ethics are issues on which experts desire the largest increase during the next 10 years. This may be because of their great importance in the past years. The financial crisis has undoubtedly marked a before and after in the Business Ethics world. Furthermore, we have social responsibility as the issue that experts want to grow below the level that they think it will really develop. This could be because, as one of Delphi experts indicated, social responsibility has come to be seen as a more important field and tends to replace Business Ethics. Therefore, corporate social responsibility has had a greater development over the past 10 years, which is why experts do not feel the need to develop it.

There is a large gap between the expected progression of each topic and the desire of the experts to progress them. This finding reflects that some topics are in some way "contaminated" because they are out of the control of real interests. One reason is the "herd effect"; it is usually easier to conduct similar research, although the contribution is not as good as that of the original authors since the innovative research lines are, in general, questioned in the sense that it is easier to contribute to a mature research line than to open a new one. One of the reasons will be that one must convince reviewers and experts about the contribution, interest, relevancy, and potential impact of the studies in that line.

\section{Business Ethics emergent issues: a brief definition}

Below are the emergent issues that were identified by participants in the first phase of the Delphi method. Below is a short description of these emergent issues. Some of them are defined in very general terms. This is because they are emergent issues, and the aim of this section is just to provide some general ideas about these expected future topics in the Business Ethics area.

\section{Gratuity and reciprocity}

Reciprocity could be defined as a mutual dependence between a company and its employees, between different employers, or between the company and external parties

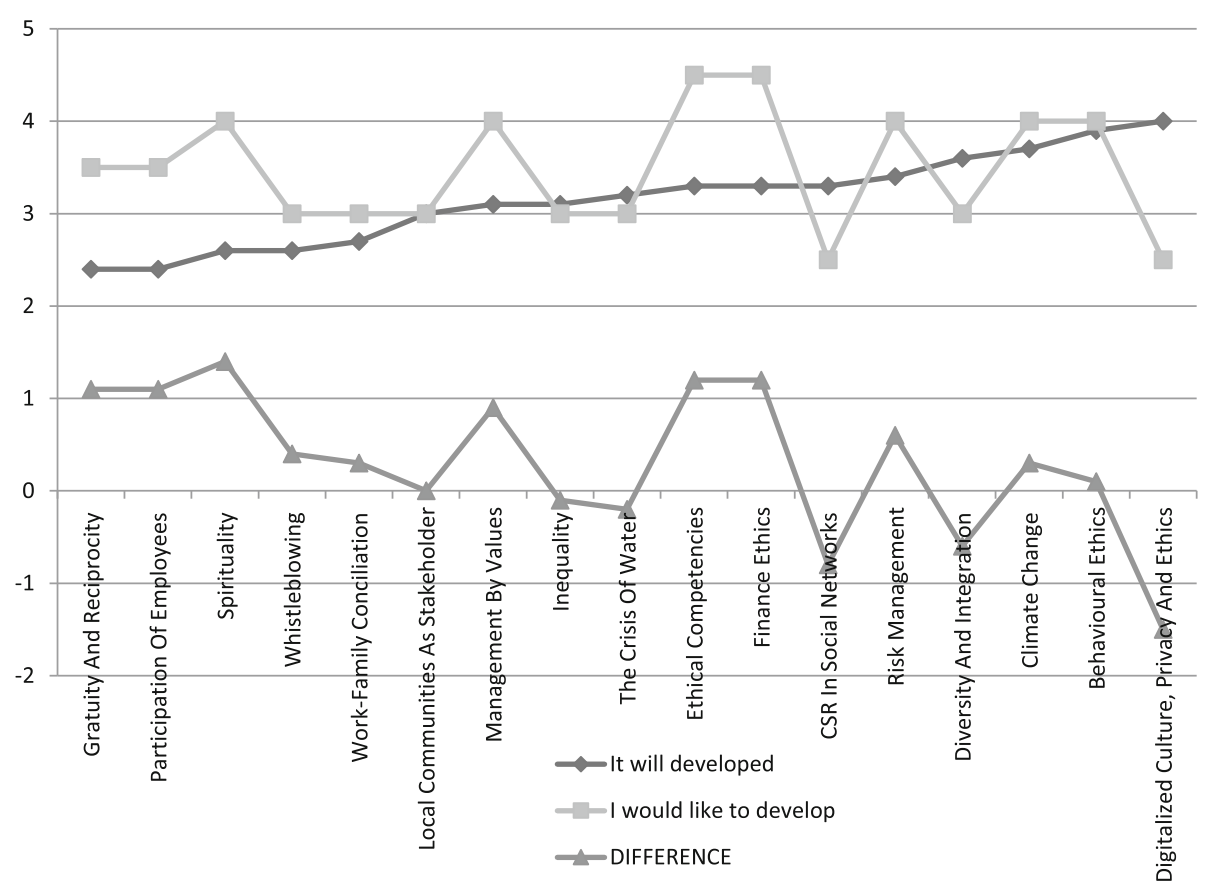

Fig. 4 Business Ethics emergent issues progression. Source: Own production 
to the firm. It is a kind of relationship between different parts of the company. Gratuity and reciprocity are "fundamental aspects of social life" ([6], p. 101).

\section{Participation of employees}

Participation occurs when employees are involved in the company's decisions and when they are part of the process in the workplace. Employees are allowed to make decisions for themselves and the company. "It is important to determinate the relevant values that influence individual, collective and organizational decision making. In essence, it is crucial that workers share the values of the organization in order to conduct themselves in agreement with the corporate identity" ([28], p. 17).

It is known that customers, employees, and people in general care about ethics. The importance of ethics in business processes forces organizations to follow strategies and to become more competitive and efficient in terms of morality.

\section{Spirituality}

"A theme emerging in the management literature is that workplace spirituality and Business Ethics are related" ([8], p. 377). There are two ways to explain this relationship: workplace spirituality perhaps stimulates the moral imaginations of people who have to address ethical issues ([14], pp. 128-139), or workplace spirituality may provide deep connections to others, thus providing rich information that better informs ethical decision-making ([15], pp. 61-70).

"Spirituality in the Workplace is about individuals and organisations seeing work as a spiritual path, as an opportunity to grow and to contribute to society in a meaningful way. It is about care, compassion and support of others; about integrity and people being true to themselves and others. It means individuals and organisations attempting to live their values more fully in the work they do" (International Center for Spirit at Work).

\section{Whistleblowing}

Many businesses demand that employees have some obligation to the company or the employer. Whistleblowing is the revelation of some wrongdoing by an employee to the public in order to be loyal to the company and to society.

"You are a whistleblower if you are a worker and you report certain types of wrongdoing. The wrongdoing you disclose must be of public interest. This means it must affect others. You are protected by law if you report a criminal offence, someone's health and safety is in danger, risk or actual damage to the environment, a miscarriage of justice, the company is breaking the law or you believe someone is covering up wrongdoing" (UK Government).

\section{Work-family conciliation}

Many European employees with children face difficulties when balancing their work and family lives. There are contracts called "flexible" employment that have been growing in Europe for the last few years. "Flexible working hours, high autonomy in the organisation of working hours and especially part-time work may facilitate reconciliation of work and family duties, but they are often accompanied by economic and career penalties" ([32], p. 528). This type of employment could have negative consequences as well, such as insecurity, worse conditions, or worse pay. A balance needs to be found in order to meet the social needs.

\section{Local communities as stakeholders}

Stakeholder refers to any individual, group, or community included among the interested parties. It is essential to identify these affected actors when a company defines and implements good project planning. Any action taken by the company affects those individuals or groups.

One type of stakeholders includes those organizations that have some interest in the project results. In this type, we include local communities. Furthermore, "while a firm affects or can affect stakeholders, stakeholders can also affect the corporation" ([11], p. 83).

\section{Managing by values}

Like Blanchard affirmed in one of his books, managing by values consists of "an incredible process that involves the entire organization in developing its mission and values. The process guarantees that your employees will enthusiastically support and apply the statements."

Managing by values uses the following instruments: mission, vision, and values.

\section{Inequality}

Inequality occurs when resources in a society are distributed unequally. That causes society to be defined by categories of persons, which is called social inequality. These different categories can reference religion, culture, race or sex, among others. This is connected to economic inequality, which describes the unequal distribution of income or wealth.

\section{The crisis of water}

Water is becoming one of the scarcest resources on the planet. Because of this, water conservation could become the new norm. "Water use has grown at more than twice the rate of population increase in the last century. By 2025, an estimated 1.8 billion people will live in areas plagued by water scarcity, with two-thirds of the world's population living in water-stressed regions as a result of use, growth, and climate change. The challenge 
we face now is how to effectively conserve, manage, and distribute the water we have" (National Geographic, www.nationalgeographic.com).

"Despite continuous investment and several efforts to control pollution, urban water environments are worsening in large parts of the developing world" ([1], p. 49). It is necessary to define a criterion for the application of reforms in order to have a good governance of water. There are basic issues to achieve effective water governance, including efficiency, responsibility, and ethics. ([23], p. 736).

\section{Ethical competences}

"In our changing global world, where we have an increasing lack of moral guidance and where we feel a greater need for knowing how to do the right thing, ethical competence stands out as an important matter to focus our interest on" (Rigas, [30], p. 55). Ethical competence "is the ability to find or to formulate the values that really matter as well as the ability to apply them in real life dilemmas and problems" ([16], p. 50). Two of the most important factors for ethical competences are education and technology.

\section{Finance ethics}

Finance is one of the most common fields in business. This issue started to be treated as a top priority at the time of crises and financial scandals.

"Finance management is beginning to emphasize ethical principles, perhaps without completely eliminating the risk of fraud or illicit behaviours but through integration, responsibility and an increase in affinity" ([4], p. 393). This makes it feasible to conduct management based on principles and values.

\section{CSR in social networks}

Corporate social responsibility (CSR) is defined as an active contribution to the social and economic improvement of companies. It includes some initiatives to value and take responsibility for the company's impact on social welfare. We can define CR without the S (Social) to adopt a more general approach and to include the environment, which is equally as important currently.

As Manuel G. Velasquez commented in a Business Ethics talk, "CSR refers to a corporation's responsibilities or obligations toward society. Business ethics is both a part of corporate social responsibility and part of the justification for corporate social responsibility." In 1991, Carrol constructed the Pyramid of Social Responsibility (as seen in Fig. 1), where ethical responsibilities are in the third position.

\section{Risk management}

Risk management is a process consisting of analyzing the dangerous effects in business. This process "involves understanding, analysing and addressing risk to make sure organisations achieve their objectives. Therefore, it must be proportionate to the complexity and type of organisation involved. Because risk is inherent in everything we do, the type of roles undertaken by risk professionals are incredibly diverse. They include roles in insurance, business continuity, health and safety, corporate governance, engineering, planning and financial services" (Institute of Risk Management).

\section{Diversity and integration}

The actual financial and economic situation has led to the growth of business integration in the world. "Among others, one element of diversity is the importance of the impact of corruption in emerging countries. Corruption decreases the credibility of financial institutions and markets" ([39], p. 481). We can find several diverse factors that affect business. Some of them could be workplace, education, or employment status.

\section{Climate change}

"The Earth's climate has changed throughout history. (...) Most of these climate changes are attributed to very small variations in Earth's orbit that change the amount of solar energy our planet receives" (NASA's Jet Propulsion Laboratory).

It is a change in the distribution of weather patterns, and one of the most important factors in climate change is business. Therefore, a range of activities that relate to global warming and specific regulations were included. Business plays a key role in the politics of global warming and in its mitigation.

As Benjamin Géminel expressed, the fight against climate change was first addressed in December 2015, and the first universal climate agreement between 195 countries occurred at the Paris Summit. The participating countries decided to adopt the Paris Agreement under the United Nations Framework Convention on Climate Change.

\section{Ethical behavior}

"Acting in ways consistent with what society and individuals typically think are good values. Ethical behaviour tends to be good for business and involves demonstrating respect for key moral principles that include honesty, fairness, equality, dignity, diversity and individual rights" (Business dictionary).

Manuel G. Velasquez defined four steps to achieve ethical behavior:

- Recognizing that a situation is an ethical situation

- Judging the ethical course of action requires moral reasoning

- Deciding to perform the ethical course of action or deciding to do what is ethical

- Conducting the ethical decision 


\section{Digitalized culture, privacy, and ethics}

We are living a digital age that is changing many aspects of life regarding the political, social, economic, and cultural factors of the world. This change is needed to prevent unethical attitudes. Business communications can be improperly used, and the results on the company can be dramatic. "It would not be an exaggeration to say that many of the new ethical problems we are facing today are related to the information revolution" ([12], p. 650).

\section{European emerging issues in Business Ethics map}

We asked the experts to name any research group, institution, or center in Europe focused on each of the emergent issues and to identify its country of origin. In the following table (Fig. 5), each emergent issue is represented. Each emergent issue is broken down into different lines. Each line references a Business Ethics expert's name, the institution or center to which he belongs, and the countries where these institutions dealing with the emergent issues are based.

This European research group, experts, and organization map in Business Ethics could be an important contribution to senior or junior academics, to experts, and to Business Ethics research groups. There was a gap in the literature, and with this Delphi process, we have contributed to reducing that gap. As we can see in the figure above, the most cited country is Spain. This could be because Spain is one of the most prominent Business Ethics document publishers (14.16\%) and may have some relationship with the level of Business Ethics courses in both private and public universities.

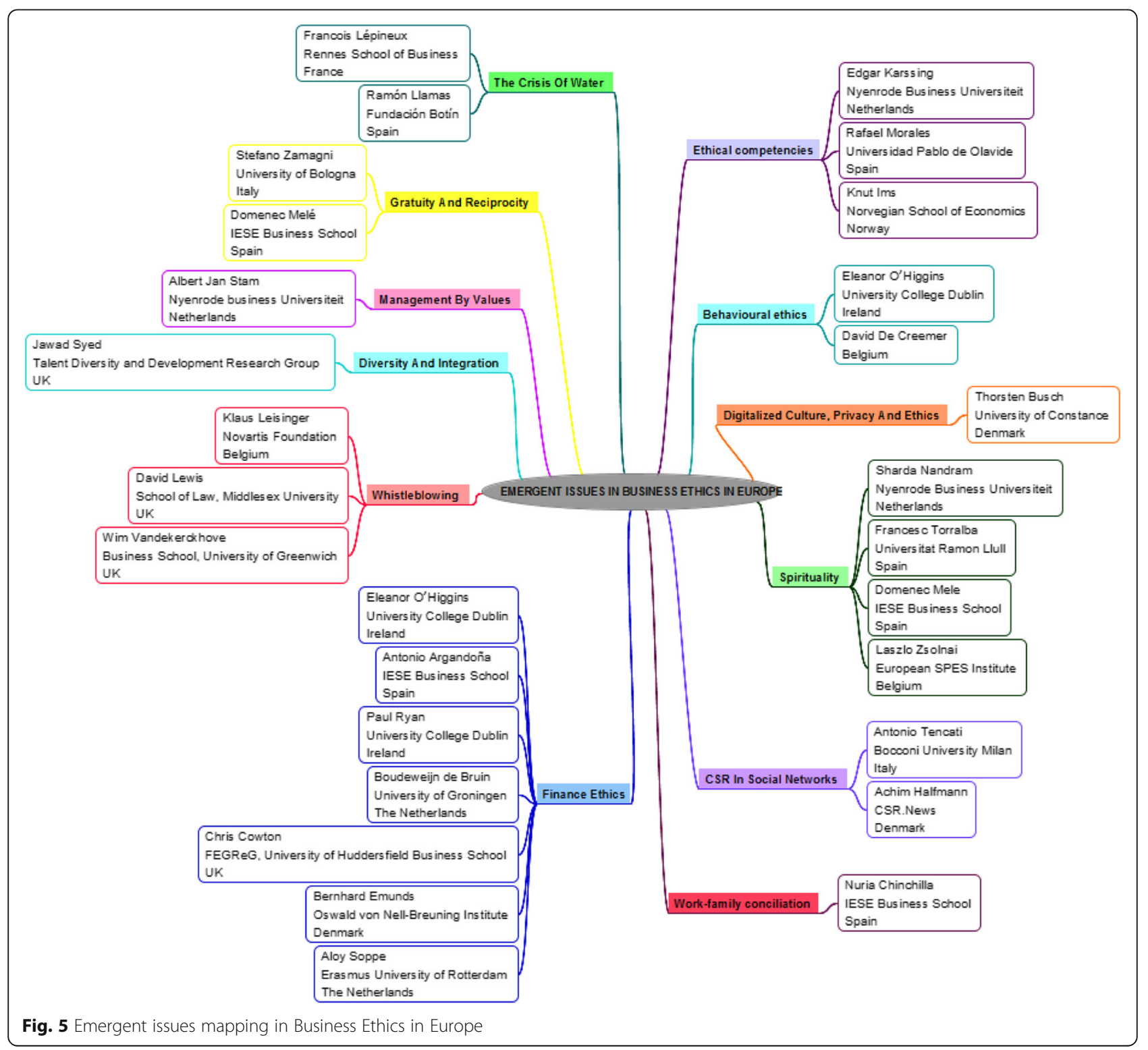


However, the country with the most Business Ethics publications is the UK (as we mentioned in the literature review based on the Web of Science journals). In truth, there is not much of a difference between the two. The UK and Spain are the countries with the highest number of Business Ethics articles published (26.74 and 14.65\%, respectively) and the most cited countries by the experts. Therefore, the results given by the experts and the Web of Science search results overlap regarding the two countries with the most research groups, institutions, or centers and the most Business Ethics publications. Since these countries are the most active and remembered ones, it could imply an effort to spread their results and contributions in society.

\section{Schools' progress in Business Ethics}

Currently business schools are not including (at least not systematically) Business Ethics aspects in their curricula [17]. Furthermore, it has been found that more than half of Master's degree students have cheated in their classes [21]. Such unethical behavior negatively affects day-to-day business decisions because those who graduated without ethical awareness are the managers who choose the options, rules, and norms of companies [34].

This issue is a concern for the scientific community. Then, we wanted to assess the evolution of Business Ethics teaching in Europe. In the graphic, we can see if the number of schools in Europe that are teaching Business Ethics has grown, stayed the same, or decreased depending on the experts' view. It is important to emphasize that this Business Ethics teaching research is focused on the last 10 years.

There is no doubt that in Fig. 6, for the most part, the number of schools teaching Business Ethics has grown over the past 10 years. For example, schools have started social responsibility programs. However, many compulsory courses in Business Ethics became elective and/or transformed into other types of courses. It is in this case that we include social responsibility as a subject linked to Business Ethics. Then, if social responsibility is included, the interest has increased.

One of the Delphi experts informed us that the term "CSR" has tended to replace "Business Ethics," especially in the teaching curriculum. He states that, "much depends on whether one distinguishes between Business Ethics and CSR. Many academics think that Business Ethics is more focused on ethical decision making in general."

In Europe, the public concern about the moral aspects of business behavior is increasing. This increase is reflected in the programs of business studies offered by various European universities and business schools.

It is true that only one third of accredited business schools offered ethics courses in 2004. In 2010, "we have found continuing growth in CSR education in Europe. The growth was most marked among dedicated Masters." ([35], p. 5). This suggests that the Business Ethics teaching offered by business schools has become somewhat more mature during recent years.

According to Swanson and Fisher [35], European countries that teach the most courses in Business Ethics are the UK and Spain. They used Spain for conducting their research. This could be in line with the previous analysis in which Spain and UK are the most cited countries regarding to the number of research groups, institutions, or centers dedicated to Business Ethics emergent issues by experts. Moreover, the UK is the first and Spain and the Netherlands are the second and third European countries with the most Business Ethics publications in the SSCI.

\section{Conclusions}

Business is easy to define, but that is not the case with Business Ethics. We have introduced different points of

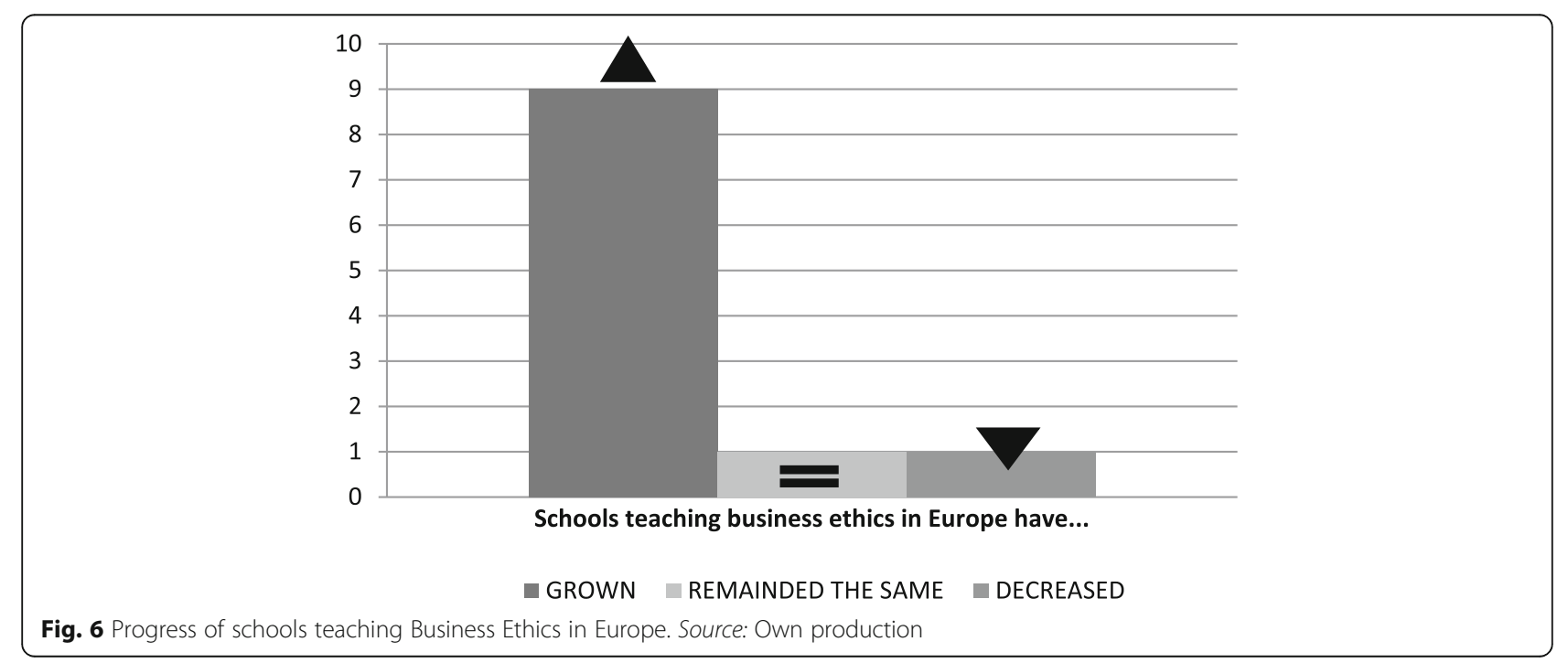


view with the goal of better understanding this term. There is a gap in the literature that establishes and reviews the Business Ethics agenda, and this study has tried to contribute in this line.

To accomplish this aim, we analyzed all steps of the Delphi method and the results around the emergent issues in Business Ethics, their development and schools' progress in Business Ethics. We can now draw some conclusions that contribute to the Business Ethics literature and future researchers.

After using the Delphi method in which 12 academic Business Ethics experts from eight European countries participated (considering the quantity of publications in Journal Citation Report journals as the criterion for being academic expert), we have produced both a map of emergent issues and a map of researchers/institutions. The European experts accepted the maps. Then, the consensus about the expected emergent issues and the knowledge about experts of the area is relevant because it illustrates the notoriety of Business Ethics topics and researchers, at least among other Business Ethics experts.

In this list of 17 emergent issues, ethical competencies, behavioral ethics, spirituality, finance ethics, risk management, and digitalized culture, privacy, and ethics are the most important. These 17 emergent issues could help to provide an understanding to interested researchers, schools, and institutions in Business Ethics in Europe. Not only future topics but also the possibility to establish a consensus among Business Ethics experts in this regard are important. These results open the windows for collaborations and makes rigorous contributions in those accepted emergent topics.

Furthermore, we have made a map of European academic Business Ethics experts to show other researchers and society which are the most important experts, organizations, and research groups in Business Ethics in Europe and their countries. Regarding schools, it is perceived as progress that lets us know that students ask for new models. Additionally, it increased the importance given by students to Business Ethics topics.

There are some potential limitations that could result from the criteria used to select Business Ethics experts, since some non-English speakers are not totally considered. For example, Spanish, German, and French Business Ethics experts are less likely to be included as panelists since they use their own languages for publishing. Moreover, Business Ethics has been considered unique in Europe, but obviously, Business Ethics could have different points and perspectives depending on the country.

Several issues could be studied in future research. First, the growth in teaching Business Ethics in European schools and the influence of teaching Business Ethics in the growth of the interest of academics in Business Ethics is analyzable. The last research undertaken dated back to 2010. Furthermore, different ways to teach Business Ethics and its advantages in business and social issues are challenges for future studies.

\section{Endnotes}

${ }^{1}$ These graphics were designed in 2015; this is why there is a large difference between published articles and citations in 2014 and 2015 . The delay between the start of writing a paper and its final publication, which can be several years, should also be taken into account. In February 2016, the number of published articles changed its behavior from that in 2015. In 2015, the number of published articles increased to a total of 22 published items.

${ }^{2}$ It is a non-profit institution that helps improve policy and offers research and analysis to the United States Armed Forces.

\section{Acknowledgements}

We would like to thank all experts who have helped us in this project, also Alba Fernandez for her collaboration in this project. In addition, it is needed to thank the support of ECRI Research Group GIU15/10 and UPV/EHU project US17/24. The ISBEE president during the study in 2015 comments and useful ideas have been essential for getting integrity and coherency for the process; moreover, her help has been relevant to obtain this emergent issues and researchers map useful for future academics and colleagues.

Funding

This study was funded by GIU15/10 ECRI (UPV/EHU) and US17/24 project.

Availability of data and materials

It will be possible to share the data whenever it is required directly to the authors.

Authors' contributions

Both authors read and approved the final manuscript.

Competing interests

The authors declare that they have no competing interests.

\section{Publisher's Note}

Springer Nature remains neutral with regard to jurisdictional claims in published maps and institutional affiliations.

\section{Author details}

${ }^{1}$ University of the Basque Country, UPV/EHU, Bilbao, Spain. ${ }^{2}$ University of Huddersfield, Huddersfield, UK. 3 University of Deusto, Bilbao, Spain.

Received: 29 December 2017 Accepted: 21 June 2018

Published online: 13 July 2018

\section{References}

1. Bader HP, Huang DB, Scheidegger R, Schertenleib R, Gujer W (2007) Confronting limitations: new solutions requires for urban water management in Kunming City. J Environ Manag 48:49-61

2. Bhattacharya M, Petrick I, Mullen T, Kvasny L (2011) A Delphi study of RFID applicable business processes and value chain activities in retail. J Technol Manag Innov 6(3):63-81

3. Brown BB (1968) Delphi process: a methodology used for the elicitation of opinions of experts (No. RAND-P-3925). RAND Corp., Santa Monica

4. Cowton C (2002) Integrity, responsibility and affinity: three aspects of ethics in banking. Bus Ethics 11(4):393-400

5. Cyphert FR, Gant WL (1971) The Delphi technique: a case study. Phi Delta Kappan 52(5):272-273 
6. Deckop J, Cirka CC, Andersson L (2003) Doing unto others: the reciprocity of helping behavior in organizations. J Bus Ethics 47(2):101-113

7. DeGeroge, R.T. (2015) A History of Business Ethics. Available at https://www. scu.edu/ethics/focus-areas/business-ethics/resources/a-history-of-businessethics/ (21 February 2018)

8. Doyle P (2009) Workplace spirituality and business ethics: insights from an eastern spiritual tradition. J Bus Ethics 85(3):377-389

9. Enderle G (1996) A comparison of business ethics in North America and Continental Europe. Bus Ethics 5(1):33-46

10. Enderle G (2013) Wall street values: business ethics and the global financial crisis. In: Santoro MA \& Strauss RJ. Cambridge University Press, New York

11. Fassin $Y$ (2012) Stakeholder management, reciprocity and stakeholder responsibility. J Bus Ethics 109(1):83-96

12. Floridi $L$ (2009) Network ethics: information and business ethics in a networked society. J Bus Ethics 90(4):649-659

13. Gentile, V. (2011) Business ethics. Bankpedia Rev 1, 17-26.

14. Gull G, Doh J (2004) The transmutation of the organization: toward a more spiritual workplace. J Manag Inq 13(2):128-139

15. Jackson K (1999) Spirituality as a foundation for freedom and creative imagination in international business ethics. J Bus Ethics 19(1):61-70

16. Kavathatzopoulos I (2003) The use of information and communication technology in the training for ethical competence in business. J Bus Ethics 48(1):43-51

17. Krehmeyer D (2007) Teaching business ethics: a critical need. Available via Business Week online. http://www.businessweek.com. Accessed 14 June 2015

18. Landeta J (2006) Current validity of the Delphi method in social sciences. Technol Forecast Soc Chang 73(5):467-482

19. Lewis PV (1985) Defining 'business ethics': like nailing jello to a wall. J Bus Ethics 4(5):377-383

20. Marcoux, A. (2008) "Business ethics." In Stanford Encyclopedia of Philosophy. Stanford: The Metaphysics Research Lab, Center for the Study of Language and Information, Stanford University. (http://plato.stanford.edu/entries/ ethics-business/)

21. McCabe DL, Butterfield KD, Trevino LK (2006) Academic dishonesty in graduate business programs: prevalence, causes, and proposed action. Acad Manag Learn Educ 5(3):294-305

22. Melé D (2008) Business ethics: Europe versus America. In Leadership and business ethics (pp. 13-27). Springer: Netherlands.

23. Mohamed MM (2009) A numerical method to index the risk of conflict around the transboundary water resources. Water Resour Dev 36(6):731-742

24. Moorhouse J (2002) Desired characteristics of ethical leaders in business, educational, political and religious organizations from East Tennessee: a Delphi investigation. Electronic theses and dissertations. Paper no 709. Available via: http://dc.etsu.edu/etd/709. Accessed 15 Jun 2015

25. Okoli C, Pawlowski SD (2004) The Delphi method as a research tool: an example, design considerations and applications. Inform Manag 42(1):15-29

26. Palazzo B (2002) US-American and German business ethics: an intercultura comparison. J Bus Ethics 41(3):195-216

27. Pätäri S (2010) Industry-and company-level factors influencing the development of the forest energy business - insights from a Delphi study. Technol Forecast Soc Chang 77(1):94-109

28. Peguero E, Berenguera A, Pujol-Ribera E, Roman B, Prieto CM, Terribas N (2015) The workers opinions have a value in the Code of Ethics: analysis of the contributions of workers in virtual Forum Catalan Institute of Health. BMC Med Ethics 16(1):90-108

29. Resick CJ, Martin GS, Keating MA, Dickson MW, Kwan HK, Peng C (2011) What ethical leadership means to me: Asian, American, and European perspectives. J Bus Ethics 101(3):435-457

30. Kavathatzopoulos I, Rigas G (2006). A measurement model for ethical competence in business. Journal of Business Ethics Education, 3, 55-74

31. San-Jose L, Retolaza JL (2016) Is the Delphi method valid for business ethics? Eur J Fut Res 4(1):1-19

32. Scherer S (2009) The social consequences of insecure jobs. Soc Indic Res 93(3):527-547

33. Schmiedel T, Vom Brocke J, Recker J (2013) Which cultural values matter to business process management? Results from a global Delphi study. Bus Process Manag J 19(2):292-317

34. Shin JC, Harman G (2009) New challenges for higher education: global and Asia-Pacific perspectives. Asia Pac Educ Rev 10(1):1-13

35. Swanson D, Fisher S (2010) Toward assessing business ethics Education. Information Age Publishing, Charlotte
36. Tersine RJ, Riggs WE (1976) The Delphi technique: a long-range planning tool. Bus Horiz 19(2):51-56

37. Turoff M (1970) The design of a policy Delphi. Technol Forecast Soc Chang 2(2):149-171

38. Van Dijk JA (1990) Delphi questionnaires versus individual and group interviews: a comparison case. Technol Forecast Soc Chang 37(3):293-304

39. Venard B, Hanafi M (2008) Organizational isomorphism and corruption in financial institutions: empirical research in emerging countries. J Bus Ethics 81(2):481-498

40. Werhane PH, Freeman RE (1999) Business ethics: the state of the art. Int J Manag Rev 1(1):1-16

\section{Submit your manuscript to a SpringerOpen ${ }^{\circ}$ journal and benefit from:}

- Convenient online submission

- Rigorous peer review

- Open access: articles freely available online

- High visibility within the field

- Retaining the copyright to your article

Submit your next manuscript at $>$ springeropen.com 